DOI: $10.17516 / 1997-1370-0718$

УДК 796.03:378.4

\title{
The Impact of the Winter Universiade-2019 on a Russian University Sport Development
}

\author{
Vladimir I. Kolmakov* \\ Siberian Federal University \\ Krasnoyarsk, Russian Federation \\ Institute of Biophysics SB RAS \\ FRC "Krasnoyarsk Scientific Center SB RAS" \\ Krasnoyarsk, Russian Federation
}

Received 05.10.2020, received in revised form 11.01.2020, accepted 29.01.2021

\begin{abstract}
The tangible and intangible legacy of the World Universiades is a debatable topic in the science literature of the world. The Universiade-2019 has become a powerful stimulus for the development of sports education, science, mass and elite student sports at Siberian Federal University (SibFU). In the field of physical culture and sports SibFU has implemented new educational programs, held international scientific conferences, carried out major scientific projects, and built a new infrastructure. The number of students involved in physical culture and sports on a regular basis has increased. Since 2012, SibFU students began to win medals at all major international student competitions, such as the European and World Championships, European Universities Games and the Universiade. For example, according to the results of the Universiade-2019, SibFU took second place among all universities in the world in terms of the number of medals won. It is concluded that the Universiadecan contribute not only to the traditional national, cultural and sports goals, but also to the development of university sports in cities hosting mega-events. An effective way to implement this idea may be to include universities in the Universiade organizing committees. The experience of SibFU in the preparation and holding of the Universiade-2019 can be recommended for replication and successful holding of future Universiades or other international student sports events.
\end{abstract}

Keywords: Universiade, sport mega-events, university sports, sports legacy, sports education and science.

Research area: physical education.

Citation: Kolmakov, V.I. (2021). The impact of the winter Universiade-2019 on a Russian university sport development. J. Sib. Fed. Univ. Humanit. Soc. Sci., 14(2), 266-273. DOI: 10.17516/1997-13700718 .

\footnotetext{
(C) Siberian Federal University. All rights reserved

* Corresponding author E-mail address: vkolmakov@sfu-kras.ru ORCID: 0000-0002-9643-609X (Kolmakov)
} 


\title{
Влияние зимней Универсиады-2019 на развитие спорта в российском университете
}

\author{
В.И. Колмаков \\ Сибирский федеральный университет \\ Российская Федераџия, Красноярск \\ Институт биофизики СО РАН \\ ФИЦ «Красноярский научный ичентр СО РАН» \\ Российская Федерация, Красноярск
}

\begin{abstract}
Аннотация. Материальное и нематериальное наследие всемирных универсиад продолжает оставаться дискуссионной темой в мировой научной литературе. В статье проанализировано спортивное наследие Всемирной зимней Универсиады-2019 для Сибирского федерального университета (СФУ). Подготовка и проведение в Красноярске спортивного мегасобытия стали для университета стимулом в развитии спортивного образования и науки, а также внесли вклад в развитие элитного и массового студенческого спорта. В области физической культуры и спорта в СФУ реализованы новые образовательные программы, проведены международные научные конференции, выполнены крупные научные проекты, построена новая инфраструктура. В университете возросло количество студентов, занимающихся на постоянной основе физической культурой и спортом. Начиная с 2012 года студенты СФУ стали завоевывать медали на всех крупных международных студенческих соревнованиях, таких как чемпионаты Европы и мира, Европейские университетские игры и Универсиады. По количеству завоеванных медалей на Универсиаде-2019 СФУ занял второе место среди всех университетов мира. Сделан вывод, что Универсиада может способствовать развитию спорта в университетах, расположенных в городах, принимающих Универсиады. Опыт СФУ по подготовке и проведению Универсиады-2019 можно рекомендовать для тиражирования и успешного проведения будущих Универсиад или других международных студенческих спортивных мегасобытий.
\end{abstract}

Ключевые слова: Универсиада, спортивные мегасобытия, университетский спорт, спортивное наследие, спортивное образование и наука.

Научная специальность: 13.00.04 - теория и методика физического воспитания.

\section{Introduction}

The policy of creating a positive image and promoting the global status of a country, city or region through holding major sport events on its territory is a well-known global practice (Black, 2017; Chu, 2018; He et al., 2020; Kobierecki, Strozek, 2020). For these purposes, some countries started to use World Universiades along with the potentially economically profitable Olympic Games, Championships and World Cups (Won, Chiu, 2020). Universiades or World University Games is an international multisport and cultural mega-event that takes place every two years (summer and winter) in different cities under the patronage of International University Sports Federation (FISU). As a rule, Universiades do not bring direct commercial benefits to competition organizers. Therefore, it was previously believed that the Universiade, like other professional games (World Police and Fire Games, Military World Games), should be held in cities that have already hosted the Olympic Games, or have a developed sports infrastructure. Later it was conceptualized that the Universiade had a long successful history and became a recognizable global brand (Lemus-Delgado, 2020). An 
idea emerged to hold the Universiade in cities with large universities and that require «revitalization» of various spheres of life. Moreover, in accordance with the current FISU policy, applications from such cities are preferred, especially when they suggest the development of sports activities in universities and colleges.

At the beginning of the $21^{\text {st }}$ century, in contrast to the backdrop of accelerating globalization processes, the competition for world leadership in the educational services market intensified (Aithal, Aithal, 2019). Under these conditions, European and Asian universities started to consider the development of student sports as one of the ways to increase their competitiveness and reputation.

Student sport is regulated by special rules developed by FISU. In particular, the Gaudeamus anthem is performed in honor of the winners; the policy of sanctions and restrictions on participation of individual countries and participants is not used, etc. The abovementioned activities benefit to the reputation and international cooperation of any university, as well as attract new applicants. Therefore, university administrations adopted conscious policy of holding international student sporting megaevents on their territory. It is considered to be extremely beneficial to host the FISU World University Championships, Cups and Games, as well as the EUSA (European University Sports Association) similar sports events. However, the most important student games are the World Universiades. The idea of developing universities through holding the Winter Universiade on their territory was most clearly realized in China (Harbin-2009) and Turkey (Erzurum-2011). The villages hosting participants and delegation leaders at Harbin-2009 and Erzurum-2011 were located in campuses of local universities. This experience was adopted in Russia and used at the Kazan-2013 and Krasnoyarsk-2019 Universiades. It is assumed that this experience will be applied in the future at the summer Universiade in Yekaterinburg-2023.

Universiade-2019 in Krasnoyarsk has already become history. The time for a thorough analysis and assessment of the strong and weak points, organizational findings and omissions has come. This article is devoted to the analysis of Winter Universiade-2019 sports legacy for mass and professional sports, education, science, infrastructure at Siberian Federal University (SibFU). It is assumed that the development of university sports under the influence of the Universiade is a new positive argument for governments and local authorities in favor of holding international student games.

\section{Theoretical framework}

A mega-event has an impact on all areas of society (Thomson et al., 2019). The impact which persists for a longer time than the megaevent itself is a legacy (Taks et al., 2015). It can be tangible and intangible, planned and unplanned, positive and negative, various in duration and space (Hover et al., 2016; Noor, 2020; Oliveira et al., 2020). A legacy can be formed before, during, and after a mega event. It is important to note that legacy can be both positive and negative (Lauermann, 2019). As a rule, a comparative method is used to assess legacy. With this approach, legacy is the difference between an «event case» and a "control case», i. e. University development without a megaevent.

As a major mega-event the Universiade in Krasnoyarsk-2019 had a planned tangible and intangible sport legacy. According to the decision of the Universiade-2019 Organizing Committee, the SibFU was chosen as one of the «subjects» of this legacy. Thus, the university campus provided accommodation for participants of the student games. The Government of the Russian Federation allocated state funding for the construction of new sports infrastructure on the campus as well as for the reconstruction of already existing objects. Strategically planned comprehensive program for the development of sports at the university took into account the influence of the World Universiade. It extended to various areas of sports activities, for example, training of highly qualified personnel in the field of physical culture and sports, sports science, professional and amateur sport, etc. Implementation of the measures was carried out at the expense of the modern soft power policy (Marklund, 2020). That is, with the involvement of the active part 
of students and the creation of the image of SibFU as an open, hospitable and dynamically developing university. The main goal of the Program is to turn SibFU into a world-class sports university, both in terms of elite achievements in student sports and mass sports.

\section{Results and Discussion}

Students are the most enthusiastic group for the promotion of major events at the university. Before the Universiade-2019, university students survay was conducted in order to study their opinion on the impact of student games on the SibFU development. A target sample of 307 respondents was used ( $26 \%$ of the respondents were men and $74 \%$ women, age range 17-25 years). The results indicated a support for student games and a sense of pride at the university as a host. The respondents also spoke out that Universiade-2019 will strengthen the university's sports infrastructure and reputation. It should be noted that the opinion of the respondents was somewhat different from the position of the Krasnoyarsk city residents in general. The citizens expressed their concern about the lack of awareness of the plans of the game organizers and demonstrated more doubt about the Universiade-2019 success. This situation occurred probably due to the traditionally low confidence of citizens in the government and its initiatives (Timoshkin, 2020). The distrust and skepticism of residents regarding promises to implement grandiose projects often accompany major sporting events (Lauermann, 2019).

Siberian Federal University was at the epicenter of the Universiade events for two weeks which provided a unique opportunity to advertise its achievements in sports, promote sports, scientific and educational developments, and agitate applicants to enter sports training areas. It is known that sports mega-events can act as advertising tools to improve or create the image of the host in the competitive market (Jeong et al., 2019). An example of creating a successful sports brand as a result of mega-events is the Chinese University of Science and Technology of Qingdao (Qingdao University of Science and Technology). After several major sailing competitions held in Qingdao, the local university began to position itself as the «University of Sails» (Jin, 2018). Universiade-2019 did not become the reason for the formation of a new sports brand of SibFU, but made a significant contribution to strengthening the university's international reputation in the field of sports. The positive information about SibFU was reported in mass media: Internet publications, newspapers, Eurosport, Sport-TV, etc. However, the most important source of information was student competitors. Every day they shared their positive opinions about competitions and their experience of living on the university campus via the Internet, especially through social networks such as Facebook, Instagram and YouTube. During the games, international social networks showed a strong dataflow of positive information about sports in SibFU, whereas online queries about SibFU increased in Google, Yandex and other search engines. This allowed potential applicants from Russia and other countries to get additional reliable information about the university. They learned that there is a university in Siberia where they can successfully combine studying and playing sports.

Universiade-2019 has had a positive impact on the SibFU reputation as «the leader in world student sports.» According to the results of Universiade-2019, SibFU took the second place among all universities in the world in the number of medals won (Table 1). University students became medalists in six of the eleven sports represented in the competition program. It should be noted that in the Universiade preceding period, university students successfully overcame the «sieve» of all-Russian qualifying competitions and achieved victories at the international level. It follows from Table 1 that SibFU became a university, which students not only participated, but also became winners in all major world and European student sports competitions from 2012 to 2019. At the same time, they won medals in 20 sports $(8-$ winter, 12 - summer). This unique achievement is the direct legacy of Universiade-2019.

SibFU success in elite student sports is not accidental. It has been achieved thanks to the implementation of the classic «pyramid» in sports training: from mass sports to the highest achievements in student sports. In accordance 
with the Program for the Mass Sports Development, the university introduced training in 17 sports at physical education classes, organized mass university tournaments and sports competitions, sections and competitions for sports fans. As a result, the number of students engaged in physical culture and sports on an ongoing basis has significantly increased (from $30 \%$ in 2012 to $38 \%$ in 2019). In winter sports context the most popular among students were snowboarding, cross country skiing and alpine skiing. Thus, the Universiade-2019 acted as a stimulator of hundreds of students engaged in physical activity and sports on a permanent basis.

It is known that the main difficulty for talented student-athletes is in the combining of higher education and sports. The implementation of such a «double career» (sports and higher education) is important for expanding opportunities and future roles in society after stopping sports activity (Condello et al., 2019). In SibFU, the support for elite student athletes includes flexible educational programs, remote studying, grant (financial or service) support, a system of individual contracts and sponsorship agreements. This provides a successful dual career for the majority of elite student athletes. As a result, a large number of students at SibFU have the title of «Master of Sports of the Russian Federation» (90 in 2019) and participate in the student teams of Russia (68 in 2019).

Since the filing of the official application of Krasnoyarsk for the Universiade-2019, SibFU has planned more than 50 events and projects aimed at the sports development. The most important events in the field of sports education, science, infrastructure and social activity are presented in Table 2. All the events listed in table 2 are related to the Universiade-2019 and are part of its legacy. Since 1998, training in the field of physical education and sports has been carried out at SibFU. However, only the Universiade-2019 allowed the university to attract significant financial, technical and human resources for the further development of higher sports education. As a result of the government order, the university created new master's training courses in the management and operation of sports facilities, as well as sports management. The main work place for graduates of these programs is Universiade-2019 sports facilities, regional sports organizations and clubs.

It is known that students of sports institutes and departments are considered to be the most motivated and successful sports volunteers and assistant judges ( $\mathrm{Lu}$ et al., 2019). Such students demonstrategood physical fitness and the above average level of essential knowledge of the competition rules. Therefore, the supplementary education programs «Sports Volunteer» and «Sports Judge», implemented during the preparation of the Universiade-2019, were mainly aimed at students studying in the field of sports. As a result of the training, students did not only improve their professional competencies, but also gained practical experience for holding high-level future major competitions in the region. As a rule, sports studies at the university were applied in nature and were carried out in the interests of coaches of regional teams. In connection with the Universiade-2019, the research policy has changed. The university launched fundamental research in the field of student and professional sports, successfully completed several research projects commissioned by state research funds. Universiade-2019 contributed to the development and expansion of interdisciplinary scientific research in the field of sports and allowed to organize a number of international scientific conferences and seminars at the university. The range of scientific topics and the coverage of sports have expanded. It is almost unbelievable, but SibFU has become a center for research and organization of scientific events not only in traditional sports for the university (for example, ski orienteering), but also for the sports that are exotic in harsh weather conditions of Siberia (golf). University researchers began to publish scientific articles on the history of student sports, and SibFU publishing house printed a number of books on the history of world sports.

The Universiade 2019 Village was designed to showcase a unique sporting identity. When implementing the plan for the construction of a sports infrastructure on the campus, in preparation for the Universiade-2019, the organizers faced the problems typical of any 
major events. These problems are the following: limited time for the design and construction of sports facilities, complicated bureaucratic procedures for determining contractors and allocation of budget funds, the need to comply with conflicting legislation on safety and environmental protection. However, these challenges had a positive outcome. Firstly, a team of university managers was formed, who gained experience in solving complex managerial and technological problems in the sports industry. Secondly, after Universiade-2019, the university campus is a high-tech, comfortable and safe area for sports and a healthy lifestyle. The infrastructure on campus allows students to engage in more than 70 summer and winter sports. The medical support system (MSS) of student athletes is a necessary component of any Universiade (Gallo-Vallejo et al., 2017). A new medical infrastructure was created on the campus at Universiade-2019, based on a newly built Medical Center (student clinic). A feature of Universiade-2019 was that after the megaevent, the MSS became a part of medical care for students on the university campus. In everyday life, the university healthcare system serves mass competitions, provides first aid and outpatient medical care, and prevents emergencies and infectious diseases. After Universiade-2019, the SibFU MSS received a powerful impetus for development. It became possible to monitor the students' health throughout their studies and residency on the university campus. That is, the student plays sports on campus, taking into account the recommendations of medical professionals and under their supervision.

The changes associated with the preparation and holding of the mega-event in Krasnoyarsk significantly increased the feeling of pride and sports patriotism among Siberian students. By carrying out a series of public events (Universiade torch relay, "Student Fan Program», etc.), it was possible to change the mindset of students concerning physical education and sport. In fact, for SibFU students, often experiencing a feeling of deep provincial- ity, a spiritual impulse was created for «moving up» through sports and physical education.

Are there any flaws in the sports legacy of the Universiade 2019? Of course there are. The non-transparency in Universiade-2019 planning, the inadequate information coverage of mass university sports and the preparation of student athletes for participation in the megaevent led to faults that have also became part of the legacy. However, the scale of the negative sports legacy is small and incomparable with the positive outcomes of the Universiade.

\section{Conclusion}

The World Universiades are reminiscent of the Olympic Games in the scale and multidisciplinarity of mega-events. However, unlike the Olympics, the concept of the Universiade, along with traditional political, cultural and sports values, should imply the development of university sports. One of the effective mechanisms for achieving this goal is the development of local universities as the «subjects» of the Universiade organization. Firstly, it complements the national tasks that the state sets by accepting the obligation to host the Universiade. Secondly, it helps to attract students to participate in the mega-event and the development of university sports in general.

Universiade-2019 was not only successfully held in a complex international climate, but also gave impetus to the development of sports at the largest university in Siberia. Therefore, the experience, methodology and basic functioning of SibFU in the preparation and conduction of the Universiade-2019 can be recommended for replication and successful conduction of future Universiades or other international student sports events. This article concludes on the short-term (1 year) positive legacy of the Universiade-2019 for the development of sports in Siberian Federal University. For the full understanding of the impact of the Universiade-2019 on the development of the university, it is necessary to continue the evaluation of the legacy of the mega-sports event. 


\section{References}

Aithal, P.S., Aithal, Sh. (2019). Building world-class universities: Some insights and predictions. In International Journal of Management, Technology, and Social Sciences, 4(2), 13-35.

Black, D.R. (2017). Managing the mega-event 'habit': Canada as serial user. In International Journal of Sport Policy and Politics, 9(2), 219-235. doi.org/10.1080/19406940.2016.1220411

Chu, M.P. (2018). China's decisiveness in Olympic bids: Leveraging international sporting mega-events to improve Beijing's odds of success. In The International Journal of the History of Sport, 35(12-13), 13061324. doi.org/10.1080/09523367.2019.1593146

Condello, G., Capranica, L., Doupona, M., Varga, K., Burk, V. (2019). Dual-career through the elite university student-athletes' lenses: The international FISU-EAS survey. In PLoS One, 14(10), 1-18. doi. org/10.1371/journal.pone.0223278

Gallo-Vallejo, M.A., De la Cruz-Marquez, J.C., De la Cruz-Campos, A., De la Cruz-Campos, J.C., Pestana-Melero, F.L., Carmona-Ruiz, G., Gallo-Galan, L.M. (2017). Sports injuries and illnesses during the Granada Winter Universiade 2015. In BMJ Open Sport and Exercise Medicine, 2, 1-8. DOI: 10.1136/ bmjsem-2016-000123

He, B., Zhu, L., Cai, X., Li, J., Zhu, H. (2020). Examining the impacts of mega-events on urban development using coupling analysis: A case study of the Boao Forum for Asia. In Sustainability, 12(2), 1-14. doi.org/10.3390/su12020730

Hover, P., Dijk, D. Breedveld, K., Van Elkeren, F., Slender, H. (2016). Creating social impact with sport events. Utrecht, Mulier Institute and Utrecht University, $51 \mathrm{p}$.

Jeong, Y., Kim, S.K., Yu, J.G. (2019). Determinants of behavioral intentions in the context of sport tourism with the aim of sustaining sporting destinations. In Sustainability, 11, 3073-3088.

Jin, Y-Q. (2018). The importance of sailing teaching in the sailing simulation training classroom-taking the sailing course in Qingdao University of Science and Technology as an example. In Asian Social Science, 14(12), 232-235. doi:10.5539/ass.v14n12p232

Kobierecki, M.M., Strozek, P. (2020). Sports megaevents and shaping the international image of states: how hosting the Olympic Games and FIFA World Cups affects interest in host nations. In International Politics. doi.org/10.1057/s41311-020-00216-w

Lauermann, J. (2019). The urban polities of mega-events. In Environment and Society: Advances in Research, 10, 48-62. doi.org/10.3167/ares.2019.100104

Lemus-Delgado, D. (2020). International sports events and national identity: the opening ceremony of the Taipei Universiade. In Sport in Society. doi.org/10.1080/17430437.2020.1732929

Lu, W.Ch., Cheng, Ch.-F., Lin, Sh.-H., Chen, M.-Y. (2019). Sport volunteering and well-being among college students. In Current Psychology, 38, 1215-1224. doi.org/10.1007/s12144-017-9663-z

Marklund, C. (2020). Soft power. In International Encyclopedia of Human Geography, 2, $291-296$. doi.org/10.1016/B978-0-08-102295-5.10706-1

Noor, M.K. (2020). The Los Angeles Olympic Games: Planning legacies. Springer Briefs in Geography, 60 p. doi.org/10.1007/978-3-030-38553-8_1

Oliveira, F.L.D., Vainer, C.B., Mascarenhas, G., Bienenstein, G., Braathen, E. (2020). Mega-events, legacies and impacts: notes on 2016 Rio de Janeiro Olympics. In International Journal of Urban Sustainable Development, 12(1), 89-102. doi.org/10.1080/19463138.2019.1650748

Taks, M., Chalip, L., Green, B.C. (2015). Impacts and strategic outcomes from non-mega sport events for local communities. In European Sport Management Quarterly, 15(1), 1-6. doi:10.1080/16184742.2014. 995116

Thomson, A., Cuskelly, G., Toohey, K., Kennelly, M., Burton, P., Fredline, L. (2019). Sport event legacy: A systematic quantitative review of literature. In Sport Management Review, 22, 295-321. doi. $\operatorname{org} / 10.1016 /$ j.smr.2018.06.011

Timoshkin, D.O. (2020). "Vas zdes' bolshe ne zhivet": Vnutrenniaia kolonizatsiia i gorodskie rezhimy Irkutska i Krasnoiarska v gorodskikh media ["You are no longer here": Domestic colonization and urban 
political regimes of Irkutsk and Krasnoyarsk in city-level media]. In Politea [Politeia], 1(96), 98-116. DOI: 10.30570/2078-5089-2020-96-1-98-116

Won, D., Chiu, W. (2020). Politics, place and nation: comparing the hosting of sport events in Korea and Taiwan. In Sport in Society: Cultures, Commerce, Media, Politics, 23(1), 142-158. doi.org/10.1080/174 30437.2018.1555911 